Transitions

$\mathrm{X}$ Steve Holmes has been appointed as senior director, therapeutic targets at Domantis, a drugdiscovery company based in Cambridge, UK. Holmes was formerly director of antibody discovery at Oxford GlycoSciences.

$\mathrm{X}$ Oxford drugdiscovery firm Etiologics has appointed David Campbell as chief scientific officer. He was previously director and head of molecular genetics, Europe, at GlaxoSmithKline.

X Nastech

Pharmaceutical in

Bothell, Washington, recently appointed Jade Brown as senior director, marketing and business development

$X$ Reinhard Schneider, a founder and chief information officer of LION Bioscience in Heidelberg, Germany, is leaving the company.

X Astex Technology, a drug-discovery firm in Cambridge, UK, has appointed David Rees director of medicinal chemistry.

X Bernard Silverman, professor and provost of the Institute for

Advanced Studies at the University of Bristol, UK, and a member of the government's GM Science Review Panel, will become master of St Peter's College, Oxford, in October.

X Jim Kennedy lecturer at the department of Earth sciences and curator of the University of Oxford's geological collection, is the new director of the Oxford University Museum of Natural History. He succeeds Keith Thomas in October.

X Mark Rohrbaugh has been appointed director of the Office of Technology Transfer in the Office of Intramura Research at the US National Institutes of Health.

\section{MEDICAL RESEARCH}

Last month, Raynard Kington was appointed as deputy director of the US National Institutes of Health (NIH). He replaces Ruth Kirschstein, who had been in the post since 1993. Kirschstein, who was also acting director for the NIH from January 2000 to May 2002, will now be the senior adviser to the agency's director, Elias Zerhouni.

Kington had been associate director for behavioural and social-sciences research at the NIH, as well as director of the NIH Office of Behavioral and Social Sciences Research since November 2000. He also served as acting director for the National Institute on Alcohol Abuse and Alcoholism for nine months in 2002.

He came to the NIH from the Centers for Disease Control and Prevention, where he oversaw surveys of the health and related behaviour of the US population.

After 30 years at the NIH, Wendy Baldwin has returned to her Alma Mater. Baldwin has been deputy director for extramural research at the NIH since 1993, but this January she joined the University of Kentucky as vice-president of research. There she will oversee an enterprise that increased its grants and contracts awards by $22 \%$ for the year 2001-02. Such growth is not unfamiliar to Baldwin - she oversaw extramural grants at the NIH during a period of rapid growth for the agency's budget.

The US National Institute on Drug Abuse in Bethesda, Maryland, has a new director. Starting next month, Nora Volkow will take over the reins from Glen Hanson, who has been acting director of the institute since December 2001.

Volkow received her medical training in Mexico, but came to the United States to do a postdoc in psychiatry at New York University and has stayed in the state ever since. She is currently associate director for life sciences at the Brookhaven National Laboratory and associate dean for the medical school at the Stony Brook University in New York.

\section{STEM-CELL RESEARCH}

Evan Snyder, who is perhaps best known for his work in neural migration and plasticity, last month joined the Burnham Institute in La Jolla, California, as director of its stemcell and regeneration programme.

Snyder is making the move from Harvard Medical School where, in his words, he has spent "half my life and my entire career". Although he stresses that he has enjoyed his time at Harvard, Snyder admits that he had become increasingly

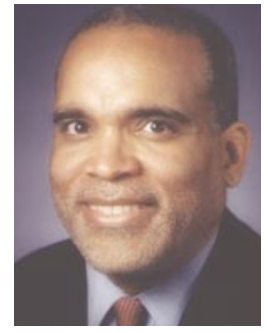

Raynard Kington

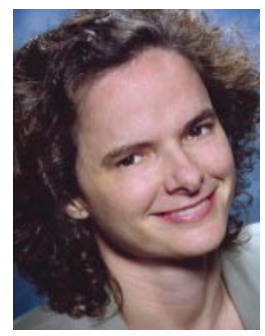

Nora Volkow

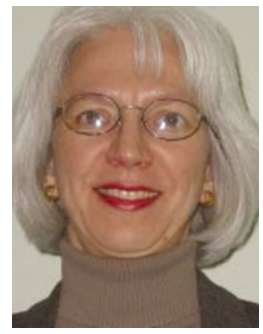

Susan Abmayr

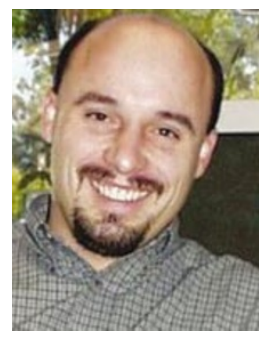

Michael Washbum

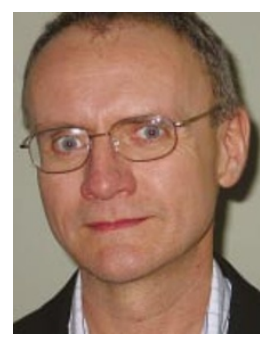

Jerry Workman

\section{CONTACTING US} AT MOVERS

Please send any information on appointments or job moves to:

naturejobseditor

@naturedc.com aware that a lot of work in his field was progressing at "nimble" research institutions, rather than at universities. Many of these institutes, like Burnham, were in the San Diego area, he adds.

California has an additional attraction for Snyder - the state government has passed a law saying that stem-cell research should be unfettered by politics. Although this legislation is largely symbolic, it signalled that the state is unlikely to interfere with his plans for stem-cell research at Burnham. These plans include the possible development of facilities to derive stem cells from human embryos work that can only be funded by private money according to current US law.

\section{GENETICS AND PROTEOMICS}

The Stowers Institute for Medical Research in Kansas City, Missouri, has added another three scientists to its roster, bringing its total headcount to 18 . The centre's good facilities, sizeable endowment (about $\$ 1$ billion) and lack of tenure are proving to be a major draw.

Susan Abmayr, who joins the institute in July as an associate scientist, was attracted by the prospect of easy access to equipment. At Pennsylvania State University in University Park, where she is currently associate professor of molecular genetics, faculty members have to share a confocal microscope, Abmayr notes. At Stowers, she says, she will have her own imaging equipment.

An added attraction is the institute's focus on science, which Abmayr feels will allow her to pursue her work on the genetics of muscle development unimpeded by other duties. "I like teaching," she says. "But between teaching and committee work, you spend so much time away from the science in your lab."

Michael Washburn will also join the institute in July, when he will leave the Torrey Mesa Research Institute in San Diego to become Stowers' director of proteomics. He will be responsible for setting up and running the institute's proteomics facility.

He says that he was attracted to the position because it will allow him to manage a facility as well as conduct his own research. He is also enthusiastic about the rapidly growing reputation of the institute, which only opened its doors in 2000.

Jerry Workman, who has been at Pennsylvania State University since 1992, is the third of the institute's new recruits. He comes in as a senior scientist. Workman is a leader in studying how chromatin, the protein-associated form of DNA, modulates gene expression. 